Vol. 17, $n^{\circ} 1 \mid 2013$

Varia

\title{
The Practise of Pastoral Power : The Swedish Prison Chaplains in the $19^{\text {th }}$ Century
}

\section{Roddy Nilsson}

\section{(2) OpenEdition \\ 1 Journals}

Electronic version

URL: https://journals.openedition.org/chs/1411

DOI: $10.4000 /$ chs. 1411

ISSN: 1663-4837

Publisher

Librairie Droz

Printed version

Date of publication: 1 May 2013

Number of pages: $53-76$

ISBN: 978-2-600-01718-2

ISSN: 1422-0857

\section{Electronic reference}

Roddy Nilsson, "The Practise of Pastoral Power : The Swedish Prison Chaplains in the 19 ${ }^{\text {th }}$ Century", Crime, Histoire \& Sociétés / Crime, History \& Societies [Online], Vol. 17, $n^{\circ} 1$ | 2013, Online since 01 May 2016, connection on 22 March 2022. URL: http://journals.openedition.org/chs/1411 ; DOI: https:// doi.org/10.4000/chs.1411 


\title{
The Practise of Pastoral Power: The Swedish Prison Chaplains in the $19^{\text {th }}$ Century
}

\author{
Roddy Nilsson
}

Cet article s'intéresse à la représentation du criminel élaborée par les aumôniers des prisons suédoises au cours du XIX ${ }^{e}$ siècle. En suivant Michel Foucault, on peut caractériser ces représentations et ces relations comme un pouvoir pastoral. Au XIX ${ }^{e}$ siècle, les aumôniers jouèrent un rôle très important dans les prisons, en partie en raison de leur statut clérical, mais aussi du fait de leur influence croissante dans les débats relatifs à la délinquance et aux châtiments. L'auteur estime que de plusieurs points de vue, les aumôniers pénitentiaires élaborèrent une conception plus subtile du délinquant et des complexités de la criminalité que celle de beaucoup des premiers psychiatres ou spécialistes d'anthropologie criminelle. Cette compréhension découlait principalement des connaissances acquises par eux au sein des établissements pénitentiaires. Au milieu du XIX ${ }^{e}$ siècle, les aumôniers assignaient en général une cause morale à la délinquance, due au défaut de connaissance et de pénétration des vérités du christianisme. Toutefois, vers le dernier quart du siècle, les références aux facteurs sociaux et structurels prirent une place croissante au sein d'explications de la délinquance devenues plus générales et plus hétérogènes. Mais en accordant à des facteurs extérieurs à la morale un rôle de plus en plus central, les aumôniers finirent par compromettre leur propre autorité en tant qu'experts de la délinquance ainsi que le statut même de la religion dans le système carcéral.

This article analyses the images of the criminal that Swedish prison chaplains developed during the $19^{\text {th }}$ century. Following Michel Foucault, such images and relations are conceptualized as pastoral power. In the $19^{\text {th }}$ century prison chaplains occupied a very important position within prisons, due partly to their status as clergymen, but also to their increasing influence on debates about crime and punishment. This article argues that in many respects prison chaplains came to develop a more sophisticated understanding of the criminal and the complexities of criminality, compared to many early psychiatrists and criminal anthropologists. This understanding was primarily the result of knowledge-gathering which took place within the penitentiaries. In the mid-nineteenth century prison chaplains generally depicted crime as morally

\footnotetext{
Roddy Nilsson is senior lecturer in criminology and associate professor in history at Linnæus University, Växjö, Sweden. His latest publications include (in Swedish) Foucault. En introduktion (Malmö, Egalité, 2008) Svensk kriminalpolitik (together with Robert Andersson) (Malmö, Liber, 2009) and "The most progressive, effective correctional system in the world? The Swedish prison system in 1960s and 1970s", in Thomas Ugelvik and Jane Dullum, The Nordic model - exception or not? Exploring institutions of confinement in the Nordic context(s) (London, Routledge, 2011). Nilsson is currently working on a research project entitled "From Solitary Confinement to Electronic Monitoring : Prison, Politics, and Welfare-State in Sweden, 1940-2000".
} 
determined and as caused by the lack of knowledge and insights into the truths of Christianity. However, during the last quarter of the century, references to social and structural factors were increasingly included in broader and more heterogeneous explanations for crime. However, if non-moral factors played such a central role as the prison chaplains gradually came to assign to them, then their own authority as experts on crime as well as the status of religion within the prison system was undermined.

\section{INTRODUCTION}

When the new prisons of the penitentiary type were developed in the nineteenth century a central role was given to the prison chaplains. One of the key intensions with the penitentiaries was to attempt 'curing' prisoners, first of all through 'treatment' by the prison chaplains, over a longer or shorter period. The methods or 'systems' according to which prisoners were treated differed from country to country, but in Sweden solitary confinement became a central approach. Solitary confinement was introduced in the 1840s and was subsequently expanded in stages to finally comprising all prisoners sentenced to punishments of up to three years ${ }^{2}$. As a result the practise of solitary confinement was used more consistently than in most other countries, which strengthened the position of the prison chaplains. Thus, the prison chaplains became key agents in nineteenth century penitentiaries, those on whom much of its success ultimately depended.

In this article I discuss the notions and images of crime and criminals that appear among nineteenth century Swedish prison chaplains. Together these concepts and images formed an important discourse, which influenced contemporary debates to a considerable degree. In a wider sense, the writings and sermons by Swedish prison chaplains on crime and criminals were linked to what the criminologist John Pratt has described as "an explosion of prison discourses" in the nineteenth century $^{3}$. Discourses are formed, as well expressed, through power relations, and prison chaplains occupied a position of considerable power and influence not only in relation to prisoners but also in shaping public views on crime and criminals. More specifically, the form of power exercised by the prison chaplains could, following Foucault, be described as pastoral power. Like all sorts of power, pastoral power is tied to a specific truth-regime, i.e. systems of thought that divide what is true from what is false. From this perspective, the prison chaplain's 'expert-status' in the definition and institutional response to crime could only last as long as the concept of crime-as-sin remained a truth in the criminological discourse.

I argue that the prison chaplains have been a neglected group in historical interpretations of prisons and criminological thinking. In fact, they were the first 'treatment specialists' in the prison service at the same time as they produced a large body of criminological knowledge. Thus, in a way prison chaplains could be seen as early - and later forgotten - criminologists. Of course, this requires a slight redefinition and broadening of the concept of criminologist. For a long time this label was reserved for those who study crime and criminals from a 'scientific' point of view, focusing on explanation, causation, correlation and, most recently,

Nilsson (1999).

$3 \quad$ Pratt (2004, p. 71). 
base their theories of evidence and observation, usually working in university departments or state-sponsored research units ${ }^{4}$. But criminology is a dynamic and constantly changing body of knowledge, reflecting on the causes of crime and the study of criminals 5 . This also means that criminology should be seen as a discourse, a linguistic entity held together by its focus on certain subjects and by certain rules regarding its objects, concepts and theoretical options ${ }^{6}$. In this context one can consider the opinions of the prison chaplains as a discourse that contributed to the creation of the criminal as a special category. Including prison chaplains in the criminological discourse challenges us to adopt a sceptical attitude towards teleological views on criminology and science. It also forces us to rethink how knowledge is produced and applied through prison practises, rather than searching for some innate scientific truth. Accordingly we need to place the 'truth-claims' of the different discourses in brackets, and treat discourses as rhetorical and practical devices with the power of influencing reality.

The view of prison chaplains on crime and criminals must be understood both against transformations in society and in relation to their role inside the penitentiaries. Thus, the context of this article is a wider interest in how to understand crime as a historical and social phenomenon or, to use a broader concept, make sense of the "criminal question" in a historical perspective. ${ }^{7}$ It relates to historical debates about the origins, development and changing meanings of perceptions about 'crime', 'criminality' and 'criminals' as well as their implications in different historical contexts. The views on crime and criminals proposed by nineteenth-century prison chaplains are also worth reconsidering in a contemporary context as morality has re-emerged in criminological discussions ${ }^{8}$.

This article consists of four parts. Part one presents some theoretical and historiographical points of departure. In the second part, I describe the role of the prison chaplains in Sweden during the second half of the nineteenth century. In the third, I discuss and analyse the knowledge on crime and criminality that was produced by the practises of pastoral power. Special attention is given to the changes that can be discerned during the nineteenth century as the theological and moral discourse transformed and began to incorporate a wide range of social and structural factors. In Sweden this shift coincided with crime and other social problems becoming the subject of a heated public debate that resulted in rising tensions around the questions of crime and criminality. Lastly, I summarize my findings.

\footnotetext{
See, for instance, the discussion in Hayward, Maruna, Mooney (2010, pp. xxv-xxxi).

See, for example Pasquino (1991); Wetzell (2000, pp. 1-17).

Foucault (1991, p. 54).

7 See Loader, Sparks (2011, p. 5). Loader \& Sparks in turn quote Tamar Pitch underlining that using this concept means "that crime is not considered independently from the procedures by which it is defined, the instruments deployed in its administration and control and the politics and debates around criminal justice and public order". See Pitch (1995, p. 52).

8 See, for instance, Wikström, Sampson (2006).
} 


\section{RELIGION, RATIONALITY AND DISCIPLINE}

The central place of religion in nineteenth century prisons is well-documented and discussed in most historical accounts on the subject ${ }^{9}$. Nevertheless the thoughts and actions of the prison chaplains have attracted relatively limited interest ${ }^{10}$. Part of the explanation for this relatively limited interest in the role of religion in prison regimes during the nineteenth and twentieth centuries can be linked to the tendency of emphasizing the rational and scientific aspects of the correctional system, which left putatively irrational elements such as religion out of the narrative. This attitude towards religion in prison regimes is already discernible in nineteenth-century discourses on prisons. Many prison reformers described prisons as an arena for scientific experiments, where only the introduction of rational methods would lead to success. The most radical among this group saw the prison as a prototype of a rationally organized world, where every criminal could potentially be transformed, or at least improved. If prisons had so far failed, this was due to insufficient knowledge, and irrational factors like human passions, as well as lack of resources or corruption among the prison administration ${ }^{11}$.

Foucault constitutes a significant example of this attitude. In his famous and extremely influential - although disputed - work on the birth of the modern prison he pays very little attention to the role of prison chaplains or religion in general ${ }^{12}$. In Foucault's work, religious practises in nineteenth-century prisons as well as the role of the prison chaplains simply reflected his overall interpretation of the prison as a disciplinary and power-producing institution. Accordingly, Foucault's principal concern with religion was as a social practise ${ }^{13}$. Without entering the discussion whether Foucault underestimated or misinterpreted the role of religion in nineteenthcentury prisons and how this might be explained, Foucault arguably had a 'religious blind-spot' and failed to acknowledge that faith constituted a powerful motivation for many of those working in prisons ${ }^{14}$. It has, however, been argued that Foucault's lack of interest regarding the role of religion must be understood in relation to his general indifference to religious matters ${ }^{15}$. Another possible reason may lie in the somewhat different role that religion played in French prisons compared to the penitentiaries in protestant parts of Europe ${ }^{16}$.

What is clear however is that nineteenth-century prisons, especially in the effectuation of solitary confinement, constituted a clearly repressive form of punishment, where the aim of creating docile and obedient subjects was central. However, in almost every phase in the history of Western prisons, priests, chaplains and other representatives of religious denominations have played important roles in

$9 \quad$ E.g. Ignatieff (1978); McConville (1981); Melossi, Pavarini (1981); O’Brien (1982); Forsythe (1987, 1990); Dumm (1987); Nilsson (1999); Nutz (2001); Schauz (2008).

10 Cf. Scharff Smith (2003).

11 Nilsson (1999, pp. 211-250).

12 Foucault (1995). See also Scharff Smith (2006, p. 197f).

13 Carrette (2000, p. 110ff).

14 On the concept "religious blindspot", see Hammar (1998).

15 Carrette (2000, p. 126).

16 Spierenburg (1996); Scharff Smith (2003). 
these institutions ${ }^{17}$. In other words, pastoral power has a long history in prisons. At the same time it can be argued that pastoral power reached its fullest elaboration in nineteenth-century penitentiaries ${ }^{18}$.

In a broader perspective the significance of religious ideas in late-eighteenth and nineteenth-century penitentiaries is well documented and has been discussed by several scholars ${ }^{19}$. Most of these works can be seen a sort of 'narratives of decline', focused on describing how religious practices and theological arguments were gradually superseded by more explicitly disciplinary practices, as well as rational and scientific prison regimes and explanations of crime ${ }^{20}$. Against this, Danish historian Peter Scharff Smith has proposed the idea that religion, rather than diminishing in influence, took on new roles and functions in modern society generally and in the creation of the penitentiaries in particular ${ }^{21}$. Religion itself could also be seen as occupying a more positive and constructive function in modern society, something that could be mobilized by the individual as a 'technology of the self'. Seen in this perspective the prison chaplain's efforts to use religion as a tool for transforming the prisoners need not be simply a disciplinary and controlling strategy, but also a discourse that individuals themselves could engage with ${ }^{22}$.

\section{PRISON CHAPLAINS AND THE SWEDISH PRISON SYSTEM}

The employment of prison chaplains on a permanent basis in the Swedish prisons was the result of changes in the prison system that took place in the decades around the middle of the nineteenth century. Prison chaplains thereby obtained a more formal role within the Swedish prison system which was regulated by the national instructions of 1835 and $1846^{23}$. These instructions stated a wide range of administrative tasks and religious services as well as prescribed that chaplains should have individual conversations with prisoners "every day, or as often as possible" 24 . The instructions also made annual reports mandatory, in which the chaplains were expected to document their activities and reflect on the effects that the penitentiaries had had on the prisoners. Most important were their assessments of what was labelled the 'moral condition' of the prisoners under their care. These pastoral judgements are especially interesting as a reflection of the prison chaplains' views on crime and criminals. Thus, in the annual reports we find visualizations of the formal as well as the informal rules that underpinned the discourses on the prison regimes in place.

\footnotetext{
17 Duce (2003).

18 Cf. Golder (2007, p. 166).

19 Ignatieff (1978); McConville (1981); Forsythe (1987, 1990); Dumm (1987); Nilsson (1999); Scharff Smith (2003).

20 See, for example, McConville (1981, pp. 160ff, 356ff, 446 et passim); Melossi, Pavarini (1981, p. 154f).

21 Scharff Smith (2006, p. 199).

22 Scharff Smith (2006, p. 200). Cf. Carrette (2000, p. 145ff).

23 SFS 1835: 72 'KC till Styrelsen öfwer Fängelser och Arbets-Inrättningar i Riket, angående religionsvården för fångar'; SFS 1846: 43 'K I för predikanter vid rikets fängelser och vid kronoarbetskåren.'

24 SFS 1846: $43 \S 2$.
} 
Even though the structure of these documents follows a rather formulaic pattern, the style of the reports is predominantly narrative with distinct individual characteristics between different authors. Some prison chaplains dedicated more space than others to reflections on the underlying causes of criminality. Some were completely silent on the question of how to understand law-breaking. The fact that some of the prison chaplains wrote nothing or very little about how to explain crime could be interpreted in different ways. Unfortunately we have no way of knowing whether the opinions of the 'silent' prison chaplains diverged from their colleagues in any substantial way. It is therefore possible that a broader range of opinions existed among prison chaplains which were not expressed in the printed annual reports. However, I find it most reasonable to interpret the silence of some prison chaplains as reflecting a rather unquestioning approach, understanding crime simply as an inevitable phenomenon. It must also be remembered that the annual reports were official documents intended primarily for the prison chaplains' superiors.

It is clear that many prison chaplains were of the opinion that isolation in separate cells had many advantages: it prevented communication with other criminals, it curbed the prisoner's temperament and broke down his (criminal) will. Lastly and most importantly, it forced the prisoner to reflect on his sins ${ }^{25}$. Hence, the introduction of the solitary system created an 'ideal situation' for the chaplains. The solitary system gave the chaplains the opportunity to become individually acquainted with the prisoners and to work with them relatively undisturbed over long periods of time. However, in order to understand the prison chaplains' views on crime and criminals, it is even more important to take into account the underlying assumptions of almost every nineteenth-century prison reformer: If the nineteenth-century prison were to become a place for rehabilitation, and not just for punishment, this was to be achieved above all through religious instruction. There hardly existed any alternative model for rehabilitating criminals - the only hope for success was through the activities of prison chaplains ${ }^{26}$.

During the 1830s and 1840s, Swedish debates on prisons were strongly influenced by the ideas and experiments taking place in the Anglo-Saxon countries as well as on the European continent ${ }^{27}$. In Sweden the outcome of the battle between the systems', i.e. between the Philadelphia and Auburn systems, ended in a clear victory for the first. In the period from 1846 to 1881 more than forty new penitentiaries based on the Philadelphia model were built in Sweden. Contrary to the development in many other countries, solitary confinement expanded step by step until it finally comprised all prisoners sentenced to punishment for up to three years. For those serving longer sentences the first three years were spent in solitary confinement ${ }^{28}$. This created a situation where a large majority of the prisoners came to be held in separate cells - something that strengthened the prison chaplains' position vis$\grave{a}$-vis the prisoners. It is striking that even after it was generally recognised that

\footnotetext{
$25 \quad$ Nilsson (1999).

26 Needless to say, there existed other models for treating prisoners - deterrence, hard labour, incapacitation etc. - but whether these are to be called rehabilitative models remains, to say the least, an open question.

27 Nilsson (1999, 2002).

28 Nilsson (1999). Even though the use of solitary confinement became less strict after the First World War it was not totally abandoned in Sweden until 1945.
} 
the rehabilitative effect of solitary confinement was slight, or at least strongly overestimated, the expansion of this model continued in Sweden ${ }^{29}$. In most other countries the heydays of solitary confinement were long gone by the turn of the $20^{\text {th }}$ century and the prison development had taken a route towards different forms of congregate systems. In England, for example, the retreat from the separate system had begun already in the $1850 \mathrm{~s}^{30}$. The use of solitary confinement declined, while the primary goal of the prison system became deterrence and less eligibility for parole - symbolised in the often quoted words, "hard labour, hard fare, and hard bed"31. In the United States the decline of solitary confinement was even more evident ${ }^{32}$. Here, almost all states adopted a congregate system or - in the southern states - a penal-slavery system where the prisoners were leased out to private entrepreneurs ${ }^{33}$. In Germany and France the use of solitary confinement also declined sharply in the second half of the nineteenth century ${ }^{34}$.

So it was in the smaller countries in northern and Western Europe, rather than in France, England or the United States that solitary confinement came to play the most important role ${ }^{35}$ The expansion in Sweden of the solitary confinement system was not based on any assessment of the model's success in terms of rehabilitating offenders. Instead the expansion and the long continuation of the system need to be understood against the background of institutional factors. The most important of these was the disciplinary potential of solitary confinement. To the staff, including the prison chaplains, the spatial isolation and the rules and regulations that surrounded it provided an extremely effective form of exclusionary power. In the attempts to create a well-ordered prison, this tool guaranteed a minimum of 'system-disturbing' incidents ${ }^{36}$. Solitary confinement in the Swedish prison system also gave the prison chaplains better opportunities to encounter and really 'see' the individual than was possible for prison chaplains in many other countries where contacts with prisoners were more collective in character.

The nineteenth-century prisons chaplains' views on crime and criminality were closely tied to the hopes and aspirations that surrounded the penitentiary in general. In the new order they were entrusted with the most important tasks: to convert the sinner and criminal into a true Christian and to make him an obedient and law-abiding subject. Thus, given their central role in the penitentiaries it is hardly surprising that prison chaplains were enthusiastic supporters of this prison policy and that their annual reports around the middle of the nineteenth century became a catalogue of praise for the institutions based on solitary confinement ${ }^{37}$.

For prison chaplains the penitentiary was the remedy for the evils of crime. The official reports from The Swedish National Prison Board of the 1840s, 1850s and 1860s were full of quotations from prison chaplains in praise of the new

\footnotetext{
Nilsson (2003).

30 Henriques (1972); McConville (1981); McGowen (1995).

31 See, for example, Rawlings (1999, p. 94).

32 Johnson (2002).

33 Sellin (1976); Colvin (1997).

34 O'Brien (1982); Wright (1983); Scheerer (1996).

35 Spierenburg (1996); Nilsson (1999); Scharff Smith (2003).

36 Nilsson (2003, p. 15ff).

37 Nilsson (1999).
} 
penitentiaries and the practise of solitary confinement. The prison chaplain in the regional penitentiary in Falun can serve as an example. In his annual report of 1849 he wrote: "The great advantages of solitary confinement have now been sufficiently proved [...] those convicted of a crime seldom return". Other chaplains wrote about "happy expectations [of the penitentiary] being fulfilled", "the strong and decisive influence" of solitary confinement or about "the beneficial effects of the penitentiary". Yet another prison chaplain reported that it was his firm conviction that the introduction of the cellular system in Sweden was "one of the greatest blessings ever of the country" 38 . The examples could be multiplied ${ }^{39}$.

However, prison chaplains were, of course, part of an institutional setting. One weakness that decreased their ability to influence the prisoners was the fact that most chaplains only held part-time employments. This changed during the last decades of the nineteenth century when at least the chaplains in the larger prisons became fulltime employees of the prison service. This change strengthened their position within the prison hierarchy while at the same time increased their identification with the interests of the system. However, one sensitive issue and potential source of conflict emerged. Prison chaplains were tied to and employed by two organisations : on the one hand, the Swedish national church and, on the other, the Swedish penal administration, which was part of the judicial system and state bureaucracy. This occasionally led to a confluence of roles as the prison chaplain came to act as a sort of semi-judiciary official. Although the chaplain's powers were not legal and his authority not political in nature, and although the prison chaplain's task was simply to tutor and guide the prisoners to salvation, there is no doubt that most chaplains also felt strong loyalty towards the state and the prison system ${ }^{40}$. This loyalty became most explicit in the prison chaplains' efforts to persuade recalcitrant suspects to confess. Until 1868 a special statute was in use prescribing that persons suspected of serious crimes could be held in solitary confinement indefinitely ${ }^{41}$. While the prisoner was held in solitary confinement the prison chaplains should attempt to persuade the prisoner to confess his or her crimes. In their annual reports the prison chaplains often raised this as a problem ${ }^{42}$.

In nineteenth-century penitentiaries the contacts between prison chaplains and prisoners in their cells came to represent the only individualizing element in a more and more uniform and rule-regulated system ${ }^{43}$. As it appears from their annual reports many prison chaplains were deeply involved in discovering and understanding the individuality of the human being in front of them. Even though prison chaplains held very little formal power to influence the terms of the prison sentence, they could nevertheless make a difference through regular visits, or by giving the prisoners permissions to read books and, of course, by seeking to influence the decisions of prison governors in informal ways.

\footnotetext{
38 Nilsson (1999, p. 320) (Author's translation).

39 Nilsson (1999, pp. 321-327).

40 Here, however, a note of source criticism must be given in that this loyalty to the state and the prison system is what could be read out of the annual reports that prison chaplains sent to the central administration of the Swedish penal service. There was, however, as Martin Bergman has shown regarding prisoners condemned to death, cases where prison chaplains displayed a certain ambivalence. See Bergman (1996, pp. 133 \& 147-155).

41 Inger (1976).

42 Nilsson (1999, p. 313f).

43 Nilsson (1999).
} 


\section{THE PRISON CHAPLAINS AND PASTORAL POWER}

The chaplains held a privileged position when it came to studying criminality as they were in contact - or at least had the opportunity to meet - individual criminals every day. In their daily practice Swedish prison chaplains studied the criminals with great interest. Nineteenth-century prisons provided excellent conditions for observing the criminal as an individual because the very architecture of this institution inscribed the individual as the proper object of analysis ${ }^{44}$. Many prison chaplains stayed in office for a long time and revealed a deep commitment to their functions. Like early criminologists of the so-called positivist and sociological schools at the turn of the twentieth century the prison chaplains focused on the criminal as an individual. But, contrary to the followers of these schools, the methods of the chaplains were based on narrowing the distance between themselves and the inmates or, in a more religious terminology, between the pastor and each member of his community. Prison chaplains were not supposed to be disinterested and neutral observers, but human beings that should lead the sinners to the road to salvation.

The intensive observation and surveillance of the prisoners as well as all other forms of knowledge-gathering that the chaplains carried out could be understood in the light of the concept of pastoral power. Foucault defines pastoral power in its 'original' form as a form of power whose ultimate aim is to ensure individual salvation in the next world and to look after each individual during his whole life. Thus, in the context of prisons the task of the prison chaplains was to take care of the prisoners' souls. The individuals entrusted to them constituted their herd and, consequently, the prison chaplain was the pastor and flock leader. Finally, and perhaps most importantly, pastoral power cannot be exercised without chaplains knowing people's minds and without persuading them to reveal their innermost secrets and weaknesses ${ }^{45}$. Importantly, pastoral power is a 'caring' and productive sort of power, which also makes it hard to resist. Consequently, there is a strong reciprocity between the pastor and his flock in that the pastor exercises a minute and careful jurisdiction over the body and soul of each member of his flock in order to ensure their redemption. In turn, the members of the flock owe to the pastor total obedience, including confessions of their sins ${ }^{46}$. But Foucault also located a shift in pastoral power during the modern period, when it acquired a more 'worldly' form, while at the same time its agents began to increase in numbers ${ }^{47}$. In their dual role as both servants of the Swedish national church as well a state officials the latenineteenth-century prison, chaplains found themselves at the centre of this power transformation.

Pastoral power is based on gathering information about the individual's biography as a way of knowing him. A biography is literally a 'life description', a narrative where the author(s) in arbitrary ways orders human life retrospectively. Thus, a biography is the personal history of an individual, or a group of individuals. Writing or 'constructing' such a history requires most of all the gathering of knowledge

\footnotetext{
Garland (1985, p. 83).

45 Foucault (1983, p. 214).

46 Foucault (2007, p. 183); Golder (2007, p. 167).

47 See, for example Järvinen (2002).
} 
about the individual. On the basis of data from church and criminal archives, personal contacts and observations, prison chaplains constructed small life stories of the prisoners under their care. Prison chaplains directed their attention not so much at the individuals' external features or behaviour as to their souls with the aim of bringing about an inner transformation. Thus, prison chaplains saw human life in terms of a biography, a sequence of events and coincidences. In this they often saw the fact that a person ended up in prison as a turning point in his or her biography. It was through this biographical work that prison chaplains built their more general images of crime and criminals discussed below.

An important part of pastoral power stemmed from the fact that the biographies which were established for each of the prisoners were meant to be transferred to the prisoner so that the narrative could be internalized by the individual criminal. Only by realizing the necessity of conversion to a life in God could the prisoner be free of his sins and repay his debt to society. The theoretical foundation for this kind of thinking rested on an assumption of free will. In this view the criminal had originally chosen to break the law and to live a life in crime and sin. By holding on to the steady conviction that man is a moral creature, prison chaplains avoided the deterministic explanations which were championed by the two emerging sciences of criminal anthropology and psychology. However, as will be discussed below, while prison chaplains collected more and more knowledge on crime and criminals, the doctrine that crime was the result of individual choices came into conflict with the observations made. At the same time, the doctrine of sin and crime as individual choice prevented prison chaplains from falling into the determinism that came to dominate criminological thought from the end of the nineteenth century onwards.

\section{SWEDISH PRISON CHAPLAINS ON CRIME AND CRIMINALITY IN THE MIDDLE OF THE NINETEENTH CENTURY}

What were the views held by prison chaplains on crime and criminality? The best material for gaining an understanding of the prison chaplains' role in the nineteenthcentury prison system is their unpublished annual reports ${ }^{48}$. The penitentiaries created unprecedented opportunities for the prison chaplains to explore the moral state of the criminals. Yet, the existence of these bureaucratic procedures also shaped the prison chaplains' views on crime and criminals in many ways.

As a general rule the annual reports from the decades around the middle of the nineteenth century depicted crime as caused by moral failings and the prison chaplains often produced harsh and condemning judgements. In this they hardly differed from the views prevailing in wider society on criminals, especially on thieves. Nevertheless, their role as prison chaplains led many to reflect deeper on the reasons of crime. Towards the middle of the nineteenth century the discourse

\footnotetext{
$48 \quad$ In their annual reports (produced in two copies, one for the Swedish penal administration and one for the diocese administration) the prison chaplains - numbering around forty nationwide - summarized what at the time was described as the moral state of their prison during the preceding year. The reports are hand-written and differ in length from one to ten pages or more. The material used for this essay consists of all reports for the year 1860, 1861, 1862, 1870, 1871, 1880, 1881, 1890 and 1899 , together approximately 300 reports.
} 
of prison chaplains on crime ${ }^{49}$ was dominated by expressions such as "lack of devotion" 50 "acts of evil" "51, "moral weakness and lack of strength when it came to resisting temptations" 52 " "innate wickedness" or "obduracy" 53 . Crime was interpreted as the result of a deficient character and as a consequence of a life in moral depravity. The prison chaplains' reports showed wide discrepancies in terms of how much space was devoted to individual cases. In most cases the notes were brief even when individuals were mentioned by names. But in some cases considerable space could be used for the discussion of single individuals ${ }^{54}$. This was most common for prisoners condemned to death. This is not surprising given the central position of clergymen in such cases ${ }^{55}$. Here the prison chaplains sometimes expressed forgiveness and sympathy in addition to the usual condemnations ${ }^{56}$.

But the general condemnations expressed by the chaplains give little indication of how they judged the individuals they encountered. Although the initial attitude of prison chaplains towards the prisoners was often defined according to the crime they had committed, they also saw them as individuals. Even though the chaplains' motivations were mostly concentrated on the 'practical' matter of saving the souls of the unfortunate creatures in their flock, they could not avoid being deeply affected by the encounter with individual criminals. So when we examine more closely the views they expressed on individual cases, their judgements were fluid, constantly changing and by no means always expressed with condemnation. The aim of the chaplains was not to reach some kind of objective diagnosis, but rather to form a picture of the sinner's soul and thereby find the point where redemption might begin. Importantly, even though crime was a moral category and as such the result of a "choice to do evil' it was not understood as something following from rational calculation. Rather, for the prison chaplains it was clear that it was a choice more of the heart than of the mind, and as such a token of the innate weakness of the individual and his inability to resist temptations. So when the chaplains met the prisoner they were faced with both a criminal and a sinner. Given that sin is basically connected with the individual, for the chaplains it was logical to see crime in the same way. Justice on earth was a reflection of the justice of God and punishment was the unavoidable result of moral

49 In the following, the names in brackets refer to prison chaplains and the year(s) of the annual report. The hand written reports are held by The Swedish National Archive, Stockholm, 'Fångvårdsstyrelsens arkiv, Inkomna religionsberättelser'.

50 'Inkomna religionsberättelser', E cb:1 (1860-1861), Gefle (Nordblom, 1861); 'Inkomna religionsberättelser', E cb :5 (1870-1871), Norrköping (Petersson, 1870).

51 'Inkomna religionsberättelser', E cb:1 (1860-1861), Carlshamn (Stenhoff, 1860).

52 'Inkomna religionsberättelser', E cb:1 (1860-1861), Luleå (Burman, 1860).

53 'Inkomna religionsberättelser', E cb:1 (1860-1861), Kalmar (Fode, 1861), 'Inkomna religionsberättelser', E cb:2 (1862-1863). Norrmalm (Schultzberg, 1862).

54 See, for example, 'Inkomna religionsberättelser', E cb:1 (1860-1861): Luleå (Burman,1860); Uppsala (Nyblad, 1860) ; Alingsås (Thorell, 1861) ; Cristianstad (Björkman, 1861); Norrtälje (Tydén, 1861); Vänersborg (Holmström, 1861); E cb:2 (1862), Linköping (Cnattingius, 1862); 'Inkomna religionsberättelser', E cb:5 (1870-1871), Norrköping (Petersson, 1870).

55 Bergman (1996).

56 See, for example, 'Inkomna religionsberättelser', E cb:1 (1860-1861), Härnösand (Nordin, 1860); Malmö (Nordberg, 1861); Uppsala (Wessblad, 1861); 'Inkomna religionsberättelser', E cb :2 (18621863), Kalmar (Fode, 1862). 
evil ${ }^{57}$. Thus, in the view of prison chaplains most criminals had broken both worldly and heavenly laws. In more general terms prison chaplains saw crime as caused by a lack of knowledge, knowledge meaning insights into the truths of religion ${ }^{58}$. This corresponded to the enormous efforts made by the chaplains to get acquainted with every single prisoner individually. Beginning with what was called the 'arrival talk' or 'arrival interrogation' a power relation was established between the pastor and the prisoner, as a new member of his flock. The chaplain's aim was first of all to identify the moral state of the prisoner. Most importantly, this initial meeting was a kind of examination of the prisoner's insights into the truths of Christianity, but it also had the purpose of investigating how the prisoner understood his past life and the crimes for which he was suspected or had already been convicted. It appears from the annual reports, that when discussing individual cases the prison chaplains often refer to impressions from their first meeting with the prisoner.

Of course, the overwhelming majority of the prisoners were men. Nevertheless, prison chaplains often devoted much time to female lawbreakers, especially those who had committed what was seen as the most horrific of crimes. Different types of criminals could be placed within a hierarchy organised according to prevailing moral standards where recidivists and murderers were at the bottom. This hierarchy also had a profound gender dimension in that women's criminality was looked upon as more 'unnatural' than men's ${ }^{59}$. Prison chaplains directed much interest to female criminality and it is clear that the problem of criminal women was proportionally given more attention than male criminality in the annual rapports. This observation is in accordance with findings made by several historians who have shown how normbreaking women attracted strong interest around the turn of the twentieth century ${ }^{60}$. Women who had committed 'male' crimes, and thus challenged the dominating gender pattern, had fallen even deeper into sin than their male counterparts. Many scholars have also argued that women who committed crimes, especially violent crimes, where labelled 'doubly deviant' in the sense that they broke both the law and the dominating gender norms ${ }^{61}$. At the same time, prison chaplains could show much more sympathy and forgiveness towards criminal women, especially if they were young. This was most evident when it came to young women imprisoned for infanticide, who could even be attributed a kind of victim status ${ }^{62}$.

\section{THE LAST QUARTER OF THE NINETEENTH CENTURY: CHANGING PERCEPTIONS OF CRIME}

Although moral approaches continued to dominate among prison chaplains, social and structural explanations became a common theme in their reports over the last decades of the nineteenth century. An important catalyst for this change

\footnotetext{
57 Cf. Duce (2003, pp. 44-48).

58 E.g. 'Inkomna religionsberättelser', E cb:1 (1860-1861): Eskilstuna (Bergström, 1861), Växjö (Welander, 1861).

59 See, for example, Arnot, Usborne (1999); D'Cruze, Jackson (2009).

60 For Sweden, see for example Petersen $(1999,2001)$.

61 Zedner (1991); Lövkrona (1999); Kilday (2007); D’Cruze, Jackson (2009).

62 Nilsson (1996, p. 80).
} 
was the famine in Sweden in the late 1860s which resulted in a strong rise in the prison population. This crisis increased the awareness towards explaining the causes of crime along other lines than individual determination or moral failings. From this time onwards references to social or structural factors such as famine ${ }^{63}$, lack of work ${ }^{64}$ or unemployment ${ }^{65}$ began to appear more frequently in the chaplains' reports. In some cases moral views became integrated into more complex and multi-facetted explanations. The words of a prison chaplain from 1886 may serve as an example: "No doubt, moral weakness and immorality are among the deep causes [of crime] but social and economic problems also play essential roles" 66 . Another example was the prison chaplain at Malmö penitentiary in his characterization of thieves as a group of indolent and indifferent creatures who, lacking criminal dispositions, but exposed to extreme poverty and want, had descended into a life of drink and subsequently into crime $^{67}$. Hence, the individually determining factors were framed as elements that were combined with social factors.

At the same time the growing social and cultural consciousness often took the form of broader and more heterogeneous explanations. Thus, a plethora of observations, remarks and condemnations of different kinds could be seen. Besides the well-known moral concerns, prison chaplains pointed to everything from railway constructions ${ }^{68}$, socialism and social democracy ${ }^{69}$, to high salaries for youths ${ }^{70}$, newspapers ${ }^{71}$, the rise of modern world-views ${ }^{72}$, materialism, the party system, the factory system ${ }^{73}$, thoughtlessness ${ }^{74}$, pursuit or desire for pleasures $^{75}$, the immoral literature ${ }^{76}$, to "Strindberg and other forms of dirty literature" 77 . Another sign of a rising social awareness among prison chaplains was their increasing acknowledgement of the difficult situation facing the prisoners after their release ${ }^{78}$.

63 'Inkomna religionsberättelser', E cb :5 (1870-1871), Christianstad (Björkman, 1870), Kalmar (Fode, 1870), Luleå (Burman, 1870).

64 'Inkomna religionsberättelser', E cb :5 (1870-1871), Göteborg (Wallerius, 1870).

65 'Inkomna religionsberättelser', E cb :5 (1870-1871), Wisby (Westöö, 1870).

66 'Inkomna religionsberättelser', E cb:18 (1886), Malmö (Sjöholm, 1886).

67 'Inkomna religionsberättelser', E cb:12 (1880), Malmö (Sjöholm, 1880).

68 'Inkomna religionsberättelser', E cb:13 (1881), Carlskrona (Swedman, 1881); 'Inkomna religionsberättelser', E cb :31 (1899), Stockholm (Löfgren, 1899).

69 'Inkomna religionsberättelser', E cb:23 (1891), Eskilstuna (Kastengren, 1891), Jönköping (Winqvist, 1891).

70 'Inkomna religionsberättelser', E cb :24 (1892), Malmö (Lindhagen, 1892).

71 'Inkomna religionsberättelser', E cb :24 (1892), Göteborg (Wakenius, 1892).

72 'Inkomna religionsberättelser', E cb :23 (1891), Nya Warfvet (Henriks, 1891).

73 'Inkomna religionsberättelser', E cb:24 (1892), Eskilstuna (Kastengren, 1892).

74 'Inkomna religionsberättelser', E cb:12 (1880), Carlskrona (Swedman, 1880); 'Inkomna religionsberättelser', E cb:13 (1881), Carlskrona (Swedman, 1881).

75 'Inkomna religionsberättelser', E cb:12 (1880), Jönköping (Ekström, 1880); 'Inkomna religionsberättelser', E cb :24 (1892), Norrköping (Hylander, 1892), Ystad (Maurizson, 1892).

76 'Inkomna religionsberättelser', E cb:24 (1892), Wenersborg (Sundborg, 1892).

77 'Inkomna religionsberättelser', E cb :24 (1892), Warberg (Wallentin, 1892).

78 'Inkomna religionsberättelser', E cb:5 (1870-1871) Landskrona (Ahlgren, 1870), Norrköping (Petersson, 1870), Luleå (Burman, 1870); 'Inkomna religionsberättelser', E cb:12 (1880), Gefle (Nordblom, 1880); 'Inkomna religionsberättelser', E cb:13 (1881), Carlskrona (Swedman, 1881), 
One can observe that a new form of thinking which was more inclined towards social and structural explanations of crime took root among prison chaplains. This was equally the case for the question of morality in itself. During the last decades of the nineteenth century individual immorality or indecency was interpreted in a broader collective context as prison chaplains began to talk about how indecency had spread "like an epidemic" together with growing moral indifference and demoralizing customs ${ }^{79}$. That such explanations can be found in the annual reports also reflects the moral insecurity of this transformative period, an insecurity that showed clear signs of a 'moral panic' 80 . This moral insecurity is also reflected in the new disciplinary discourse that many prison chaplains came to adopt in the last decades of the nineteenth century when the annual reports are characterised by frequent reflections on the need for more control, above all of young people, and harsher punishments in general ${ }^{81}$.

At the same time one can observe a shift in the moral explanations, as the moral weakness which was attributed to many prisoners from the late nineteenth century was more often interpreted as the result of bad upbringing and weak parental care ${ }^{82}$. Typical were comments such as "life lived from the early years in sin and vice" ${ }^{83}$, a "depraved life-style" 84 , or "a vicious life" 85 . Some cases were identified as the result of a depraved family ${ }^{86}$, evil dispositions in the family ${ }^{87}$ or coming from a criminal family. But these expressions alluded to a social heritage, not a biological or genetic one. The same could be said when prison chaplains categorized some individuals as being "without abilities", "untalented" or having a "weak heads"

Even if alcohol abuse had been depicted as a cause of crime at least since the early nineteenth century, it was not until the last decades of the century that it became the most common theme when it came to constitute an explanation for crime ${ }^{89}$. Pointing

Stockholm (Hammarstedt, 1881), Norrmalm (Annell, 1881); 'Inkomna religionsberättelser', E cb :23 (1891), Nya Warfvet (Henriks, 1891), Långholmen (Sandberg, 1891).

79 Nilsson (1999, pp. 338-346).

80 Cohen (2002); Nilsson (2002).

81 'Inkomna religionsberättelser', E cb:12 (1880), Nya Warfvet (Ahlberg, 1880), Malmö (Sjöholm, 1880); 'Inkomna religionsberättelser', E cb:13 (1881), Långholmen (Sandberg, 1881), Norrmalm (Annell, 1881); 'Inkomna religionsberättelser', E cb:22 (1890), Långholmen (Sandberg, 1890), Jönköping (Winqvist, 1890), Karlskrona (Östergren, 1890).

82 'Inkomna religionsberättelser', E cb:12 (1880), Växjö (Wirell, 1880), Kalmar (Medelius, 1880), Carlskrona (Swedman, 1880), Norrmalm (Annell, 1881), Carlskrona (Swedman, 1881), Jönköping (Ekström, 1881) ; 'Inkomna religionsberättelser', E cb :22 (1890), Wisby (Westöö, 1890), Karlskrona (Östergren, 1890), 'Inkomna religionsberättelser', E cb:23 (1890), Eskilstuna (Kastengren,1891). But cf 'Inkomna religionsberättelser', E cb:1 (1860-1861), Alingsås (Thorell, 1861); 'Inkomna religionsberättelser', E cb :2 (1862-1863), Westerås (Pettersson, 1862).

83 'Inkomna religionsberättelser', E cb:12 (1880), Malmö (Sjöholm, 1880).

84 'Inkomna religionsberättelser', E cb :23 (1891), Nya Warfvet (Henriks, 1891).

85 'Inkomna religionsberättelser', E cb :22 (1890), Norrköping (Hylander, 1890).

86 'Inkomna religionsberättelser', E cb:12 (1880), Malmö (Sjöholm, 1880); 'Inkomna religionsberättelser', E cb :22 (1890), Nya Warfvet (Henriks, 1890).

87 'Inkomna religionsberättelser', E cb:12 (1880), Nya Warfvet (Ahlberg, 1880).

88 'Inkomna religionsberättelser', E cb:12 (1880), Carlskrona (Swedman, 1880).

89 'Inkomna religionsberättelser', E cb:12 (1880), Kalmar (Medelius, 1880), Carlskrona (Swedman, 1880), Ystad (Ling, 1880); 'Inkomna religionsberättelser', E cb:12 (1880), Norrmalm (Annell, 1881), Carlskrona (Swedman, 1881), Ystad (Ling, 1881); 'Inkomna religionsberättelser', E cb :22 
to alcohol abuse had a double function; it was framed both as a direct explanation for the crimes committed, most often violent crimes, as well as a structural explanation. From the 1880s onwards The Swedish National Prison Board gathered statistical data on the ratio of crimes committed under the influence of alcohol. Year after year the published annual reports from the Board emphasized the destructive and crime-producing effects of alcohol consumption ${ }^{90}$. For all its flaws, these statistics stood out as strong evidence of the harms produced by alcohol abuse. During Sigfrid Wieselgren's time as Governor General of the Swedish National Prison Board (18851910) drinking or intemperance was elevated to the status of 'official' and at the same time most important explanation for criminality. For example, in the published annual report for 1888 the Board stated that the statistical evidence showed that alcohol abuse stood out "most clearly" as the predominant cause of criminality . Wieselgren, who was the son of a famous pastor and leader of the temperance movement, was himself a dedicated advocate of temperance ${ }^{92}$. In the last decades of the nineteenth century alcohol abuse was labelled as the most important social problem in Sweden as well as in the other Scandinavian countries. Wieselgren's term as Governor General for the Swedish National Prison Board coincided with the break-through and upswing of the Swedish temperance movement ${ }^{93}$. From his dual position as Governor General and member of the upper chamber of the Swedish parliament Wieselgren launched a temperance campaign directed at the prisoners as well as the whole population. Temperance pamphlets were distributed to the prisons and every cell got a poster on the wall with the heading "Avoid the Pub !" The rest of the poster contained moral statements on the dangers of drink.

The attention that prison chaplains paid to alcohol as a factor of crime could be seen as a result of their changing perceptions of the social body. By the turn of the twentieth century prison chaplains came to incorporate several of the discursive elements that characterised debates on the so-called "social question". In this discourse special attention was given to conditions in the growing cities, places where alcoholism, prostitution, criminality as well as different psychical and moral deceases were said to flourish. Many prison chaplains condemned life in the cities as unhealthy and morally degenerate, especially for the young generation ${ }^{94}$. However, it is important to point out that the criticism directed against life in the expanding cities, in contrast to the putatively healthy and sound life in rural areas, should not be seen simply as a conservative reaction against the forces of modernity. The city

(1890), Eskilstuna (Kastengren, 1890), Karlskrona (Östergren, 1890), Kalmar (Lindblom, 1890); 'Inkomna religionsberättelser', E cb:23 (1891), Karlskrona (Östergren, 1891), Upsala (Martin, 1891), Norrköping (Hylander, 1891), Jönköping (Winqvist, 1891), 'Inkomna religionsberättelser', E cb:24 (1892), Nya Warfvet (Henriks, 1892), Eskilstuna (Kastengren, 1892), Malmö (Lindhagen, 1892), Halmstad (Olén, 1892), Warberg (Wallentin, 1892).

90 Nilsson (1999, p. 339, note 207).

91 Nilsson (1999, p. 346).

92 Aldén et al. (2002).

93 Johansson $(1995,2000)$.

94 'Inkomna religionsberättelser', E cb:12 (1880), Malmö (Sjöholm, 1880), Nya Warfvet (Ahlberg, 1880), Göteborg (Hellstedt, 1880); 'Inkomna religionsberättelser', E cb:22 (1890), Långholmen (Sandberg, 1890); 'Inkomna religionsberättelser', E cb:23 (1891), Nya Warfvet (Henriks, 1891), Långholmen (Sandberg, 1891). 
as a place of moral and physical degeneration was a conceptualization that was used in circles from the radical left to the reactionary right.

As the first cohorts of prison chaplains were replaced by younger generations, and as the great expectations placed on the penitentiary showed no signs of being fulfilled, a significant shift in the views on crime occurred and a more pragmatic or, in some cases, resigned attitude became evident among the prison chaplains. However, despite these changes, which were accompanied by lower expectations to the potential of the penitentiary in general, prison chaplains were never in doubt about the blessings of solitary confinement ${ }^{95}$.

\section{THE NINETEENTH-CENTURY PRISON CHAPLAINS AS EXPERTS ON CRIME}

How should these changing perceptions of crime among the prison chaplains be understood? First, it is far too easy to dismiss the knowledge produced by the prison chaplains in the last part of the nineteenth century as the result of an unreflective, unsophisticated and emotionally tinged conservatism fed by a blend of nostalgia and fear. Such an interpretation would be too simplistic. The societal discourse around the turn of the twentieth century without doubt incorporated many of these features. But rather than interpreting the prison chaplains' conceptualizations of crime and criminals as a reflection and reiteration of the dominant crime policy discourse in Swedish society at the time, the messages they sent out were vitally important in the creation and re-production of this discourse.

There is a clear pattern that those chaplains who were employed in prisons located in the major cities displayed a particularly pronounced interest in question about the causes of crime. Their positions were mostly full-time, and gave the office-holders more time to reflect on matters concerning crime. Hence, their annual reports were generally more elaborated and had a more stringent and wellstructured argumentation. Prison chaplains in the big prisons often belonged to the ecclesiastical elite, some of them holding doctoral or masters degrees. Since they lived in the bigger cities they also had better contacts with other elite groups and thus more opportunities to communicate their views.

As shown above, the prison chaplains' method of analysis was, above all, the biography. For them, the key to understanding crime lay in the life of the individual. The prison chaplains were confronted almost on a daily basis with those who had lived their entire lives in poverty and misery. When they met the prisoners face-toface they saw them as human beings, individuals with largely differing intellectual gifts and emotional powers. In the long term, the chaplains' understanding of crime and criminals gradually came to be shaped by these meetings with an endless line of people belonging to the lowest layer of agrarian communities or coming from the small but ever-growing industrial proletariat.

Chaplains became increasingly aware of the difficult social conditions that many people lived under. The methodological approach to criminals through their lifestory as well as the frequent face-to-face meetings had the effect on many prison chaplains that it undermined their belief in the Christian doctrine which held that

\footnotetext{
Nilsson (1999).
} 
crime was above all the result of individual choice and innate weakness. This led to the integration of environmental and structural factors in their explanations.

Especially the meetings with people who entered the prison for the first time, such as petty thieves or young women accused of infanticide, made strong impressions on the prison chaplains. Many of these newcomers to the prison appeared to be victims of social and economic pressures or pure want. The greater emphasis on these factors opened up for social and structural understandings of crime; this shift also led to new approaches to the prevention and 'cure' of criminality. In addition to discussions about the need for a revival of traditional Christian values, the prison chaplains of the late nineteenth century began to advocate state interventions in areas like education, employment and poor relief. This however does not imply that prison chaplains joined liberals and early socialists as advocates of progressive social and democratic reforms. On the contrary, the solutions proposed by prison chaplains were, with a few exceptions, firmly rooted in socially conservative and patriarchal discourses.

The changing discourse during the last decades of the nineteenth century also signalled a shift in explanatory style. It is clear that the prison chaplains at the end of the century lived in a society undergoing transformations of a magnitude that was impossible to ignore. There is no doubt that the chaplains were aware of the emergence of a range of new social problems, that they found deeply concerning or even frightening. Thus, the discursive change among chaplains was the result of accumulative experiences in their work, a learning-process where the older certainties no longer held sway. Even though pastoral power arguably placed the chaplain in a stronger position vis-à-vis the prisoner, it was nevertheless a relation in which the latter also influenced the actions and thinking of the former. Poverty and want among the prisoners opened the eyes of many chaplains to the fact that there existed a correlation between social conditions and crime. This made them more aware that their morally ordered worldview was insufficient when it came to explaining the increase in crime and rising prison population. This does not mean that prison chaplains abandoned their biographical gaze, only that the determining elements in these narratives changed. Of course, the transformation in the prison chaplains' views was also linked to the wider process of secularisation which, among many other things, meant that matters of faith became more private at the same time as the boundaries between the state and the church became more distinct ${ }^{96}$. By the turn of the twentieth century the Swedish national church came under pressure from different directions, both from the fast-growing evangelical and temperance movements and from socialists and other radicals.

On the other hand, the continued use of solitary confinement in Sweden helped the prison chaplains to retain a central role inside the prison system, and to uphold this position for another quarter of a century. One might argue that the establishment of prisons, mental hospitals, homes for the disabled, for the feeble-minded, for juvenile delinquents etc. which took place during the latter half of the nineteenth and first half of the twentieth centuries also confined religion to certain sectors of society. At the same time, these institutions, in a way, functioned as shelters against the ongoing processes of secularisation. In the case of Sweden the symbiosis between the state and the national church could have strengthened this tendency even further.

$96 \quad$ Bergman (1996, pp. 196-201 \& 207). 
Most importantly, prison chaplains conceptualised every prisoner as a moral agent as well as someone exposed to exterior forces. Although chaplains lacked an elaborated scientific terminology, they often conceptualised crime as grounded in "the experiences of everyday life" to borrow an expression from (post)modern cultural criminology ${ }^{97}$. When discussing whether prison chaplains should be understood as a sort of 'forgotten' criminologists it is important not to measure them and their views on crime according to the standards set up by their predecessors. Hence, what might appear at first glance as rather impressionistic and unsystematic explanations, in fact constituted what was at the time a powerful discourse on crime and criminality. It must be stressed that criminology is not only a body of knowledge intended for scientific or administrative use - it is also a public discourse that concerns the whole of society ${ }^{98}$. Thus, the knowledge produced by different groups of recognised experts on crime - such as the prison chaplains in the nineteenth century - influences public responses to crime, be it negligence or fear, social engineering or moral panic. By the turn of the twentieth century the prison chaplains constituted an important voice in the growing public debate about crime and punishment. Through their authority as experts on crime and prisons, their statements acquired considerable influence. As participants in the intensified debate on crime and other societal problems, they occasionally functioned as "policy advisors" ${ }^{99}$. The knowledge produced in the practises of pastoral power did not stay in the prison and church bureaucracies. Newspapers sometimes published the prison chaplains' reports as a sort of 'official' statement on crime, while politicians quoted them in parliamentary debates. Some of the prison chaplains were active in the public debates. As recognised experts on crime, the prison chaplains played important roles as discourse producers, above all those chaplains employed in the big city prisons. Some of them wrote books on the subject of criminality ${ }^{100}$. As a member of the upper chamber of the Swedish parliament Governor General Wieselgren used this arena as a platform to put forward his views on criminality and drunkenness ${ }^{101}$. In the late 1890 s he also led an important parliamentary commission dealing with youth criminality. The proposals presented by this commission - which later resulted in the first Swedish legislation on child and juvenile criminality - depended very much on the images of crime produced by the prison chaplains ${ }^{102}$.

Finally, the fact that many prison chaplains gradually changed their views on crime and criminals must be linked to the functioning of the penitentiary and especially to its failures in rehabilitating criminals. Given that solitary confinement continued to play a central role in the Swedish prison system together with the fact that most of the penitentiary institutions were relatively small provided the chaplains with much better opportunities than their colleagues in many other countries to obtain insight into the lives of individual inmates. When, by the turn of the twentieth century it became clear to almost everybody that the high hopes associated with the penitentiaries were not going to be fulfilled, prison chaplains who had spear-headed

\footnotetext{
97 Ferrell, Hayward, Young (2008).

98 Loader, Sparks (2011).

99 The term is borrowed from Loader, Sparks (2011, p. 30ff).

100 Lönegren (1862); Strömer (1876); Sjöholm (1878).

101 Wieselgren (1992).

102 Bjurman (1995); Nilsson (2001).
} 
these institutions came to experience the flaws of this practise particularly keenly, which often generated feelings of disappointment and disillusion. As the first group of enthusiastic prison chaplains were replaced by younger generations, and the great expectations placed on the penitentiaries showed no signs of fulfilment, a significant shift occurred. Given the central role assigned to the prison chaplains in rehabilitating the prisoners under their care, their increasing emphasis on social and structural factors - i.e factors largely outside their control - became a strategy for dealing with their own shortcomings. However, by gradually assigning more importance to socio-structural factors as an explanation of crime, prison chaplains also came to undermine their own positions in the prison system. If social and structural, i.e. non-moral, factors such as poverty, unemployment, poor housing conditions, excessive drinking etc., really played a central role in causing crime, then their authority as experts on crime, as well as the status of religion within the prison system changed. The irony is that as soon as prison chaplains started to develop more complex and sensitive views on crime and give more credence to explanations pointing in other directions than theological and moral ones their pivotal role as crime experts was undermined.

\section{PASTORAL POWER AND THE IMAGES OF CRIME}

Compared to many early psychiatrists and criminal anthropologists, not to mention the representatives of jurisprudence, nineteenth-century prison chaplains in some ways had a better understanding of man, both as a moral and as a social being. They also developed a more sophisticated understanding of criminality as a complex and contextual phenomenon. In their explanations prison chaplains, in addition to their theologically and morally grounded views, began to integrate a wide array of social, political and cultural factors in their discussions.

Central to pastoral power is that the chaplain must observe each member of his flock, i.e. their behaviour and conduct, in order to create a body of knowledge. These observations and conversations with the prisoners became the raw material for the prison chaplains' reflections on crime and criminality. In their annual reports, written correspondence, sermons and meetings with other prison administrators, bureaucrats, politicians and laymen the prison chaplains developed ideas and images of reality which in turn had implications for how crime and criminals were understood. To summarize, the Swedish prison chaplains during the second half of the nineteenth century generated and disseminated knowledge on crime in a way that made them important discourse producers, occupying an important role when it came to producing the criminal subject during this period. Thus, for better or for worse, they took part in building the moral structure of their time.

However, the dominating narrative today concerning perceptions on crime and criminality tell us that during the nineteenth and first decades of the twentieth centuries, scientific explanations gradually replaced older morally grounded ideas ${ }^{103}$. This interpretation has also permeated most of the studies in the history of criminology carried out during the last few decades, albeit in a more reflective way ${ }^{104}$.

\footnotetext{
103 See, for example, Wiener (1990); Godfrey, Lawrence (2005).

104 Garland (1985); Pick (1989); Wiener (1990); Leps (1992); Beirne (1993); Rafter (1997); Wetzell (2000); Gibson (2002); Horn (2003); Davie (2005); Wetzell, Becker (2006).
} 
In this article I have taken on the history of criminological knowledge from another angle, discussing the functions, practises and forms of knowledge that characterised Swedish prison chaplains of the latter half of the nineteenth century. I have discussed the knowledge on crime and criminals gathered by the prison chaplains as tied to the practises of pastoral power. Most often omitted from the history of early criminology - a history dominated by philosophers, doctors, psychiatrists, statisticians and psychologists - prison chaplains should be recognised as a key group of experts on crime and criminals in the nineteenth century.

As a consequence of the positivist dominance, criminological thinking and practice have labelled nineteenth-century prison chaplain's thoughts on crime and criminals as speculative, unsystematic or, at best, 'pre-scientific'. The omission of the prison chaplains from the history of criminology is not primarily the result of criminology's successes when it comes to explaining and preventing crime, but stems from its success in controlling the discourse on this topic. It should not be taken for granted that criminology during its century-long history had presented better and more valid explanations for crime than some of the discipline's predecessors. After all, the history of criminology is to a great extent a history of mystifications, mistaken routes and failures, not to talk of the human suffering that it has produced ${ }^{105}$.

Measured by the standard of today it is, of course, easy to discern many flaws and weaknesses in the images of crime and criminals that prison chaplains presented during the nineteenth century. Among these is the lack of rigorous methods and of theoretically informed terminologies as well as criteria for what counts as valid scientific explanations. However, it must be emphasized that although some prison chaplains made use of elementary statistical calculations, it was never their goal to produce scientific knowledge in the modern sense of the term. Thus, the discourse they produced belonged to a different knowledge paradigm, located in what we can call the realm of moral or existential knowledge, a knowledge paradigm where other forms of truth were produced. Therefore, it does not come as a surprise that the prison chaplains' reports lacked practically all explicit references to the new scientific discourses on crime and criminals that developed during the latter half of the nineteenth century. Furthermore, they seldom presented strictly causal or deterministic explanations of the kind that dominated the proliferating biological criminology. To them crime was above all caused by a combination of moral and, as we have seen, environmental and social forces, but never the result of strict scientific laws. Neither did they see criminals as 'dangerous' or incorrigible in same way as criminal anthropologists and other representatives of criminology began to do. Finally, they also lacked the visual approach to the criminal that students of physiognomy and phrenology produced and they provided few remarks or comments on the bodily features of the criminals and very few reflections over the connections between body and moral standard.

The different knowledge paradigms produced by prison chaplains on the one hand, and psychiatrists, psychologists and biologists on the other, represented what could be described as two rather distinct criminological ontologies, i.e. fundamental assumptions about the nature of man and society which forms the basis for answers to questions concerning the causes of crime and how to deal with it, assumptions that in the last instance are grounded in the images of man. So, on the one hand, there was

105 Cf. Cohen (1992); Ferrell, Hayward, Young (2008). 
the prison chaplains' understanding of the criminal as a fallen creature and crime as a moral and social problem, and on the other hand representatives of the new science of crime who, building on pathological models inscribed in an evolutionary naturalist discourse, emphasized deterministic models of heredity or degeneration, and thus concentrating their work on discerning habitual and dangerous criminals.

Roddy Nilsson Linnæus University

Växjö, Sweden roddy.nilsson@lnu.se

\section{SWEDISH NATIONAL ARCHIVE (STOCKHOLM)}

Fångvårdsstyrelsens arkiv

Inkomna religionsberättelser E cb:1 (1860-1861), E cb :2 (1862-1863), E cb : 5 (1870-1871), E cb:12 (1880), E cb:13 (1881), E cb:22 (1890), E cb :23 (1891), E cb:24 (1892), E cb:31 (1899).

\section{REFERENCES}

Anon., Svensk Författningssamling (SFS), official publication, Stockholm: Norstedt \& Sönner, 1835 \& 1846.

Aldén, L., Aronsson, P., Johansson, L., Phènomenet Peter Wieselgren, Växjö, Historiska Föreningen i Kronobergs län, 2002.

Arnot, M.L., Usborne, C., Gender and Crime in Modern Europe, London, University of London Press, 1999.

Bergman, M., Dödsstraffet, kyrkan och staten i Sverige från 1700-tal till 1900-tal, Lund, Rättshistoriskt bibliotek, 1996.

Beirne, P., Inventing Criminology: Essays on the Rise of 'Homo Criminalis', New York, State University of New York Press, 1993.

Bjurman, E.-L., Barnen på gatan, Stockholm, Tiden, 1995.

Carrette, J.R., Foucault and Religion: Spiritual Corporeality and Political Spirituality, London \& New York, Routledge, 2000.

Cohen, S., Against Criminology, New Brunswick and London, Transaction Publishers, 1992.

Cohen, S., Folk Devils and Moral Panics: The Creation of the Mods and Rockers, London \& New York, Routledge, 2002 [1972].

Colvin, M., Penitentiaries, reformatories, and chain gangs: social theory and the history of punishment in nineteenth-century America, Houndsmills, Macmillan, 1997.

Davie, N., Tracing the Criminal: The Rise of Scientific Criminology in Britain, 1860-1918, Oxford, The Bardwell Press, 2005.

D'Cruze, S., Jackson, L.A., Women, Crime and Justice in England since 1660, Houndsmill, Palgrave MacMillan, 2009.

Duce, A.R., A Christian approach to punishment, in McConville, S. (ed.), The Use of Punishment, Cullompton, Willan Publishing, 2003.

Dumm, T.L., Democracy and Punishment: Disciplinary Origins of the United States, Madison, University of Wisconsin Press, 1987. 
Ferrell, J., Hayward, K., Young, J., Cultural Criminology: An Invitation, London and New York, Sage, 2008.

Forsythe, W.J., The Reform of Prisoners 1830-1900, Croom Helm, 1987.

Forsythe, W.J., Penal Discipline, Reformatory Projects and the English Prison Commission 1895-1939, Exeter, University of Exeter Press, 1990.

Foucault, M., The Subject and Power, in Dreyfus, H. L., Rabinow, P., Michel Foucault: Beyond Structuralism and Hermeneutics. With an Afterword by and an Interview with Michel Foucault, Chicago, University of Chicago Press, 1983.

Foucault, M., Politics and the Study of Discourse, in Burchell, G., Gordon, C., Miller, P. (Eds), The Foucault Effect: Studies in Governmentality with two lectures by and an interview with Michel Foucault, Chicago, University of Chicago Press, 1991.

Foucault, M., Discipline and Punish: The Birth of the Prison, New York, Vintage 1995.

Foucault, M., Security, Territory, Population: Lectures at the Collège de France, 1977-1978, New York \& Basingstoke, Palgrave MacMillan, 2007.

Freeman, E.B., Their Sisters' Keepers: Women's Prison Reform in America, 1830-1930, Ann Arbour, University of Michigan Press, 1992 [1984].

Garland, D., Punishment \& Welfare: A History of Penal Strategies, Aldershot, Gower, 1985.

Gibson, M., Cesare Lombroso and the Origins of Biological Criminology, Westport, Praeger 2002.

Godfrey, B. Lawrence, P., Crime and Justice 1750-1950, Cullumpton, Willan Publishing, 2005.

Golder, B., Foucault and the Genealogy of Pastoral Power, Radical Philosophy Review, 2007, 10, 2, pp. 157-176 [http://ssrn.com/abstract=1348831].

Hammar, I., Några reflexioner kring "religionsblind" kvinnoforskning, Historisk Tidskrift, 1998, 2, pp. 2-29.

Hayward, K., Maruna, S., Mooney, J., Introduction, in Hayward, K., Maruna, S., Mooney, J., Fifty Key Thinkers in Criminology, London and New York, Routledge, 2010.

Henriques, U., The Rise and Decline of the Separate System of Prison Discipline, Past and Present, 1972, 54, pp. 61-93.

Horn, D.G., The Criminal Body: Lombroso and the Anatomy of Deviance, London and New York, Routledge, 2003.

Ignatieff, M., A Just Measure of Pain, London, Macmillan, 1978.

Inger, G., Institutet “insättande på bekännelse” i svensk processrättshistoria, Stockholm, Institutet för rättshistorisk forskning, 1976.

Järvinen, M., Hjälpens universum - ett maktperspektiv på mötet mellan klient och syste', in Meeuwisse, A., Swärd, H. (Eds), Perspektiv på sociala problem, Stockholm, Natur och kultur, 2002.

Johansson, L., Systemet lagom. Rusdrycker, intresseorganisationer och politisk kultur under förbudsdebattens tidevarv 1900-1922, Lund, Lund University Press, 1995.

Johansson, L., Sources of Nordic solutions, in Sulkunen, P., Sutton, C., Tigerstedt, C., Warpenius, K. (Eds), Broken Spirits: Power and Ideas in Nordic Alcohol Control, Helsinki, NAD Publication No. 392000.

Johnson, R., Hard Time: Understanding and Reforming the Prisons, Belmont, Wadsworth, 2002.

Kilday, A.-M., Women and Violent Crime in Enlightenment Scotland, Woodbridge, Boydell Press, 2007.

Leps, M.-C., Apprehending the Criminal: The Production of Deviance in Nineteenth-Century Discourse, Durham \& London, Duke University Press, 1992.

Loader, I., Sparks, R., Public Criminology?, London \& New York, Routledge, 2011. 
Lönegren, H.F.A., Lifvet i ett svenskt Straffängelse under 1800-talet jemte Några tankar om medlen till förekommandet af den öfverhandtagande stora brottsligheten $i$ samhället och till lifstidsfånges förbättring och upprättelse samt Ett samhälles olycksbarn, Warberg, 1862.

Lövkrona, I., Annika Larsdotter barnamörderska, Lund, Historiska Media, 1999.

McConville, S., A History of English Prison Administration. Volume 1 1750-1877, London, Routledge \& Kegan Paul, 1981.

McConville, S., English Local Prisons 1860-1900: Next only to Death, London, Routledge, 1995.

McGowen, R., The Well-Ordered Prison: England 1750-1865, in Morris, N., Rothman, D.J. (Eds), The Oxford History of the Prison: The Practise of Punishment in Western Society, Oxford, OUP, 1995.

Melossi, D., Pavarini, M., The Prison and the Factory: Origins of the Penitentiary System, London, Macmillan, 1981.

Nilsson, R., Växjöfängelsets historia 1848-1995, Norrköping, Kriminalvårdsstyrelsen, 1996.

Nilsson, R., En välbyggd maskin, en mardröm för själen. Det svenska fängelsesystemet under 1800-talet, Lund, University Press, 1999.

Nilsson, R., Sanningen om ungdomen. Normer, värderingar och föreställningar kring 1900-talets ungdom, Växjö, Centrum för kulturforskning. Växjö Universitet, 2001.

Nilsson, R., "Med hvarje år utökas ju antalet af dessa unga brottslingar". Ungdomsbrottslighet och moralisk panik, in Andersson, I., Johansson, K., Lindstedt Cronberg, M., Tid och tillit. En vänbok till Eva Österberg, Stockholm, Atlantis, 2002.

Nilsson, R., The Swedish Prison System in Historical Perspective: a Story of Successful Failure?, Journal of Scandinavian Studies in Criminology and Crime Prevention, 2003, 4, 1, pp. 1-20.

Nutz, T., Strafanstalt als Besserungsmaschine: Reformdiskurs und Gefängnisswissenschaft 1775-1848, München, Oldenbourg Verlag, 2001.

O'Brien, P., The Promise of Punishment: Prisons in Nineteenth-Century France, Princeton, Princeton University Press, 1982.

Pasquino, P., Criminology: The Birth of a Special Knowledge, in Burchell, G., Gordon, C., Miller, P. (Eds), The Foucault Effect: Studies in Governmentality with two lectures by and an interview with Michel Foucault, Chicago, University of Chicago Press, 1991.

Petersen, A., Kvinnliga brottslingar och brottsliga kvinnor. Fängelsers berättelser om kön $i$ 1800-talets Sverige, Lund, Research Report. Network for Research in Criminology and Deviant Behaviour, 1999.

Petersen, A., Kvinnor i marginalen. Könskonstruktioner i 1800-talets fängelse, in Lövkrona, I. (ed.), Mord, misshandel och sexuella övergrepp. Historiska och kulturella perspektiv på kön och våld, Lund, Nordic Academic Press, 2001, pp. 188-209.

Pick, D., Faces of Degeneration: A European Disorder, c. 1848-c. 1918, Cambridge, CUP, 1989.

Pitch, T., Limited Responsibilities, London, Routledge 1995.

Pratt, J., The acceptable prison: official discourse, truth and legitimacy in the nineteenth century, in Gilligan, G., Pratt, J. (Eds), Crime, Truth and Justice: Official inquiry, discourse, knowledge, Cullompton, Willan Publishing, 2004.

Rafter, N., Creating Born Criminals, Urbana and Chicago, University of Illinois Press, 1997.

Rawlings, P., Crime and Power: A History of Criminal Justice 1688-1998, London \& New York, Longman, 1999.

Scharff Smith, P., Moralske hospitaler. Det moderne fangselvaesens gennembrud 1770-1870, Copenhagen, Forum, 2003. 
Scharff Smith, P., A religious technology of the self: Rationality and religion in the rise of the modern penitentiary, Punishment \& Society, 2006, 6, 2, pp. 195-220.

Schauz, D., Strafen als moralische Besserung: Eine Geschichte der Straffälligenfürsorge 1777-1933, München, R. Oldenbourg Verlag, 2008.

Scheerer, S., Beyond Confinement? Notes on the History and Possible Future of Solitary Confinement in Germany, in Finzsch, N., Jütte, R. (Eds), Institutions of Confinement: Hospitals, Asylums, and Prisons in Western Europe and North America, 1500-1950, Cambridge, CUP, 1996.

Sellin, T., Slavery and the Penal System, New York, Elzevier, 1976.

Sjöholm, P.J., Om den enskilda själavården inom fängelserna, Malmö, 1878.

Spierenburg, P., Four Centuries of Prison History: Punishment, Suffering, the Body, and Power, in Finzsch, N., Jütte, R. (Eds), Institutions of Confinement: Hospitals, Asylums, and Prisons in Western Europe and North America 1500-1950, Cambridge, CUP, 2003 [1996].

Strömer, G., Om själavården inom fängelserna, Malmö, 1876.

Wetzell, R., Inventing the Criminal: A History of German Criminology 1880-1945, Chapel Hill \& London, The University of North Carolina Press, 2000.

Wetzell, R., Becker, P. (Eds), Criminals and their Scientists: The History of Criminology in International Perspective, New York \& Cambridge, CUP, 2006.

Wiener, M., Reconstructing the Criminal: Culture, Law, and Policy in England 1830-1914, Cambridge, CUP, 1990.

Wieselgren, S., Minnen från mina fångvårdsår, Stockholm, Rönnells, 1992.

Wikström, P.-O., Sampson, R.J. (Eds), The Explanation of Crime: Causes, Mechanisms and Development, Cambridge, CUP, 2006.

Wright, G., Between the Guillotine and Liberty: Two Centuries of the Crime Problem in France, New York \& Oxford, OUP, 1983.

Zedner, L., Women, Crime and Custody in Victorian England, Oxford, Clarendon, 1991. 